\title{
La Sante Nan Lavi Granmoun:
}

IFAS EXTENSION

\section{Jennifer Hillan ${ }^{2}$}

Salad fasil epi rapid! Lè ou mete salad avèk bisuit soda e pen yo fè yon sante dine. Eseye kèk ide pou lè wa-p pran yon ti salad.

Chawzi kantite leti tankou leti, romèn, fèy wouj, e fèy vèt. Sa yo gen plis nutriyan ke leti iceberg.

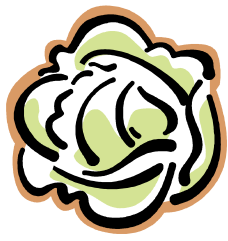

Mete tomat sou leti yo. Epi lèt kaye ki pa gen grès.

Melanje legim avèk fwi pou ka gen yon konbynezòn etranj. Eseye pòm koupe oson zoranj mandarin sou fèy zepina.

Mete nan péch oson pwa, lèt kaye oson yogout. Epi grenn manba.

Mete pwa ki soti nan bwat sou salad ou. Eksperiment avék pwa frans, pwa d'souch, pwa vét, oson pwa piti.

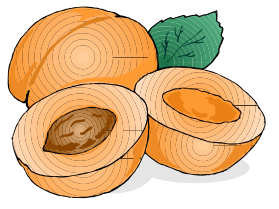

Fé yon salad avék legim ki soti nan can, epi melanje-l avék legim tankou karot, bét wouj, osnon pwa vét.
Mete pwotyen nan salad ou avék fwomaj cube, zé boui, oson vyann ki nan can.
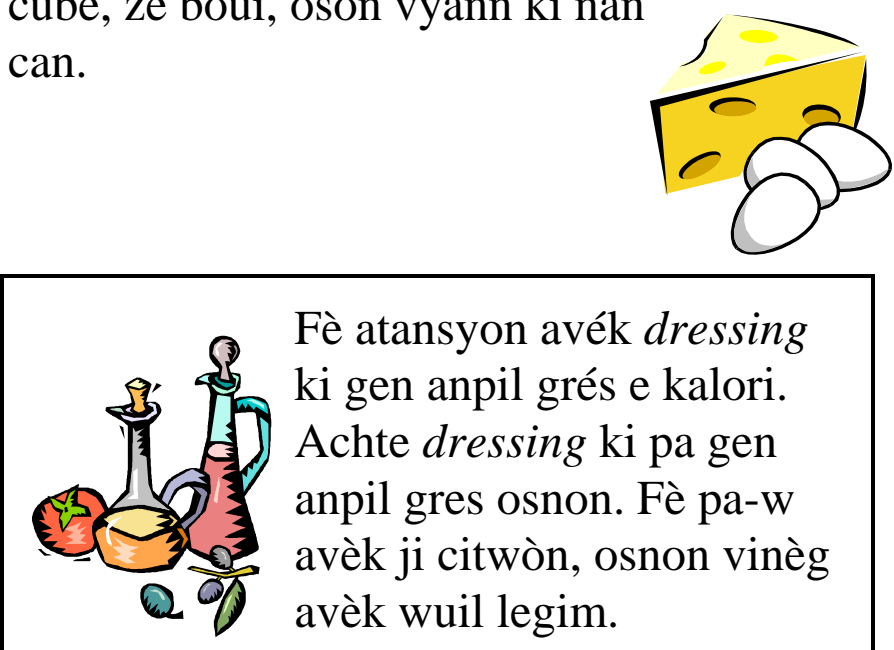

Fè atansyon avék dressing ki gen anpil grés e kalori. Achte dressing ki pa gen anpil gres osnon. Fè pa-w avèk ji citwòn, osnon vinèg avèk wuil legim.

\section{Bay Pwen}

Pa lave manje fre anvan ou prepare pou-w itilize-l, yo ap rete pi fre si ou fè sa.

Mete piman koupe avèk jonjon e zonyon nan frijidè pou-w itilize yo pou yon lòt tan.

Si li posibe, koupe leti ak melon avèk yon zanmi.

\footnotetext{
1. This document, FCS8696-Hai, is one in a series of the Department of Family, Youth and Community Sciences, Florida Cooperative Extension Service, Institute of Food and Agricultural Sciences, University of Florida, Gainesville, FL 32611. Publication date: March 2004. The English version of this Haitian Creole language leaflet is Healthy Eating for Elders: Salad Suggestions. This leaflet was developed with funding from the Florida Department of Elder Affairs in partnership with state, county, and local agencies. Please visit the EDIS Web site at http://edis.ifas.ufl.edu

2. Jennifer Hillan, MSH, RD, LD/N, former ENAFS nutrition educator/trainer, Department of Family, Youth and Community Sciences, Institute of Food and Agricultural Sciences, University of Florida, Gainesville, FL 32611. English version reviewed by Linda B. Bobroff, PhD, RD, LD/N, professor, and Leigh Ann Martin, MESS, former ENAFS project coordinator, University of Florida. Translation by Rodrique Colas, University of Florida. Translation reviewed by Jean-Elie Gilles, PhD, French and Haitian Literature, University of Florida.
} 